\title{
Successful endoscopic treatment of an unusual foreign body in the stomach: A package of heroin
}

\author{
Mehmet Asıl, M.D., Ramazan Dertli, M.D. \\ Department of Gastroenterology, Necmettin Erbakan University Meram Faculty of Medicine, Konya-Turkey
}

\begin{abstract}
Drug addiction is an important medical and social problem. "Body packing" is frequently used for concealed transportation of illegal drugs. The drug is packed in small plastic packages and swallowed or placed into body cavities, such as the rectum or the vagina. Another aspect is "body stuffing," in which the drug package is usually hastily swallowed in order to avoid arrest. Presently described is case of a body stuffer who ingested a package of heroin and was successfully treated with upper gastrointestinal endoscopy. Upper gastrointestinal endoscopy is a safe alternative therapeutic option in body stuffers in selected cases.
\end{abstract}

Keywords: Body stuffer; foreign body; heroin; upper gastrointestinal system endoscopy.

\section{INTRODUCTION}

Drug addiction is an important medical and social problem. Increasing trends of illicit drug use worldwide make it worthy of attention. Since marketing of such drugs is illegal, so-called "body packing" is frequently used for concealed transportation. ${ }^{[1]}$ The drug is usually packed in small plastic packages and swallowed or placed into body cavity, such as the rectum or the vagina, by "drug mules" to transport the hidden material. Another aspect is "body stuffing," in which the drug package is usually hastily swallowed to avoid arrest. ${ }^{[2]}$ Several complications, such as disruption of the packing material and acute intoxication due to high dose drug exposure, intestinal obstruction or perforation, or airway obstruction have been reported in body packers and body stuffers in the literature. [3] Surgery is mainstay of treatment for swallowed drug packages, particularly when drug leak and intoxication is the problem. Endoscopic removal of ingested drug packages from the stomach is also a therapeutic option, but it has rarely been reported in the literature. To our knowledge, there are only

Address for correspondence: Mehmet Asıl, M.D.

Necmettin Erbakan Üniversitesi Tıp Fakültesi Hastanesi,

Gastroenteroloji Kliniği, Konya, Turkey

Tel: +90 332 - 2236517 E-mail: drmehmetasil@yahoo.com.tr

Submitted: 24.02 .2016

Ulus Travma Acil Cerrahi Derg

Accepted: 10.11 .2016

2017;23(4):354-356

doi: $10.5505 /$ tjtes. 2017.93462

Copyright 2017

TJTES
4 cases published in the English-language literature describing endoscopic retrieval of drug packages. ${ }^{[4-7]}$ Presently described is case of a body stuffer who ingested a package of heroin and was treated with upper gastrointestinal endoscopy (UGIE).

\section{CASE REPORT}

A 29-year-old male patient was admitted to the emergency department accompanied by police and claimed to have ingested a handmade plastic package containing heroin approximately 2 hours prior to hospital arrival. He was a local drug dealer, and he stated that he ingested the heroin package on purpose in effort to destroy the evidence and avoid arrest in police raid. He didn't know exact quantity of heroin in the package, but stated that packaging of the drug had been sloppy. The heroin was wrapped in cigarette foil paper and then wrapped in plastic and taped loosely. Due to poor packaging, he was anxious about leak of contents and asked for package to be removed. He had no complaints on admission and seemed to be in good health. His blood pressure was $120 / 72 \mathrm{mmHg}$, heart rate $78 /$ min, temperature $36.8^{\circ} \mathrm{C}$, and respiration was $12 / \mathrm{min}$. Remainder of physical examination was also unremarkable. On admission, complete blood count, routine serum chemistries, including renal and liver functions, and serum electrolytes were all normal. Blood and urine toxicological tests were also found to be negative. Plain radiogram of the abdomen was obtained, but the package could not be visualized.

The patient was informed about possible complications of the ingested heroin package and treatment options were discussed. Possible complications associated with upper gastrointestinal endoscopy, foreign body retrieval, and particularly 
risk of rupture of the package during endoscopic removal were also explained to the patient and informed consent was obtained. Endoscopy was performed with topical pharynx anesthesia under conscious sedation. Endoscopic examination revealed presence of grayish-colored plastic package approximately $5 \times 3 \times 1.5 \mathrm{~cm}$ in size lying in mid corpus (Fig. I) in the stomach. Package appeared to be intact and undisrupted. It was caught with netted snare and withdrawn together with the endoscope without difficulty. After retrieval, the package was examined for any possible sign of disruption and it was found to be intact without any sign of spillage of the contents (Fig. 2). The patient was hospitalized for 24 hours for observation and discharged into police custody.

\section{DISCUSSION}

Body packing and body stuffing are 2 closely related entities in which illicit drugs are swallowed. The first report describing a body packer was published in 1975. ${ }^{[8]}$ There are several reports in the literature describing complications and management of such cases. There are several reports of cocaine having been body packed, and lethal cases of cocaine intoxication due to disruption of the packages have also been also reported. Ingestion of packages of heroin has also been reported. Naloxone is used in case of heroin toxicity. [9] Surgery is usually preferred for treatment of patients with signs of intoxication, whereas management of asymptomatic body packers is usually conservative. ${ }^{[10]}$ Most packages pass spontaneously in stools, although stool softener may be used to facilitate excretion. In case of intestinal obstruction, or when progression of package through the intestines

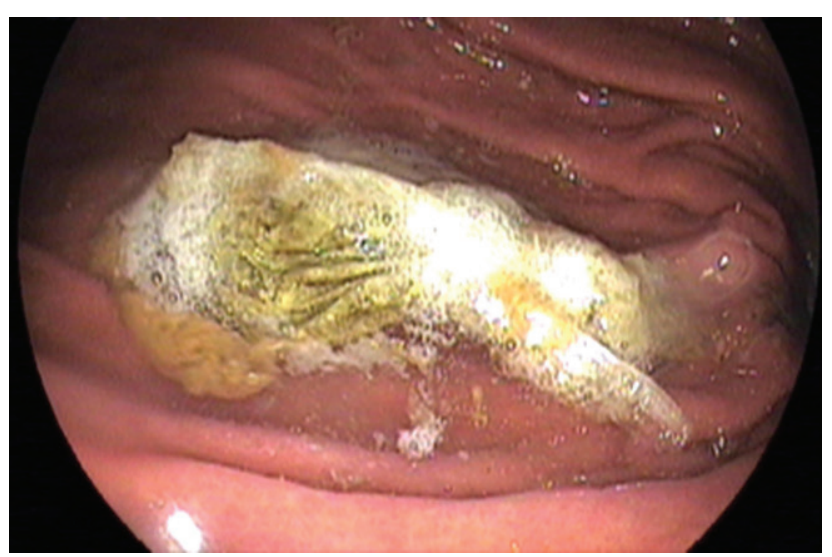

Figure 1. Heroin package observed in the stomach.

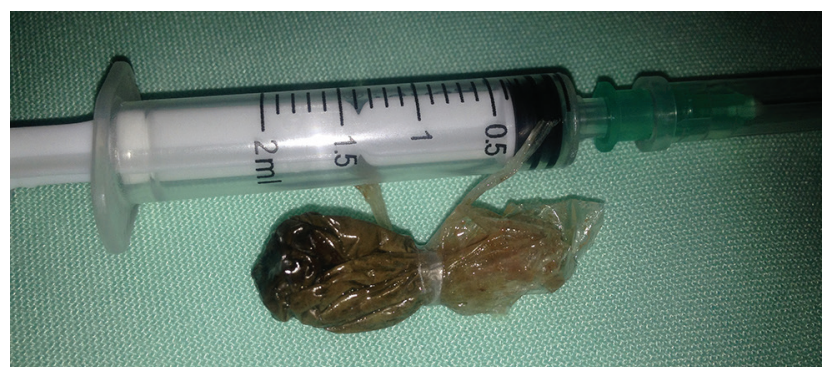

Figure 2. Retrieved heroin package. stops, surgery is again the mainstay of treatment since risk of package rupture increases with time. UGIE and colonoscopy are other therapeutic options. Packages that have not passed beyond the pylorus can be retrieved using UGIE. There are only a few reports in the literature describing retrieval of packed drugs with UGIE. We believe that this is primarily because length of time in police custody after swallowing the package in an asymptomatic body packer, or until occurrence of symptoms in complicated case, allows for passage of the drugs far beyond the pylorus. Secondly, disruption of the package and spillage of contents during endoscopic retrieval is another concern limiting use of UGIE in these patients. Particularly in case where numerous packages have been swallowed, endoscopic retrieval of all packages without disruption may be difficult. Yet there are case reports in the literature that describe successful endoscopic removal of drug packages. In our case, since the patient had swallowed only single package of heroin and he had been brought to the hospital immediately, length of time from swallowing to endoscopic intervention was short. Package was still in the stomach, allowing for endoscopic retrieval without complication. Although the patient was asymptomatic, conservative management was not planned because the patient had stated that the packaging was poorly done; therefore, there was greater risk of drug leakage and subsequent opiate intoxication. Moreover, there was strong patient will to have package removed. Surgery and endoscopy were offered as potential therapeutic interventions. The patient declined surgery. Endoscopy was performed and the package was successfully removed. ${ }^{[1]}$

In our case, endoscopic treatment was successful and without complication. Possible complications associated with endoscopic foreign body retrieval include perforation, hemorrhage, foreign body impaction, airway obstruction, and sedoanalgesia-related complications. In cases of body packers and body stuffers, particularly disruption of drug packages and spillage of contents during endoscopic retrieval with subsequent drug intoxication is a major concern. Therefore, maximal care should be taken during endoscopic intervention and retrieved packages should be carefully examined after withdrawal from the body for any sign of disruption.

Another noteworthy point is that although plain radiogram of the abdomen was obtained at the time of admission, the package couldn't be visualized. Reported sensitivity of conventional radiograms in detecting drug packages ranges from $40 \%$ to $90 \% .{ }^{[2]}$ Therefore, when plain radiogram is normal, further radiological studies, such as abdominal ultrasound, computerized tomography, or contrast passage radiograms should also be performed in suspicious cases.

One last point to mention is that although blood and urine toxicological tests were performed, they were all found to be negative. In asymptomatic body packers, diagnostic value of blood and urine toxicological tests is low, since in most cases 
the packages remain intact. Therefore, such tests should not be used alone for screening purposes in suspected cases.

In conclusion, management of body packer and body stuffer cases is still challenging sometimes. Although surgery is the preferred method of treatment in symptomatic cases, UGIE can be considered a minimally invasive therapeutic procedure that may be suitable in selected cases with no signs of toxicity, when elapsed time between swallowing and hospital arrival is short, and number of swallowed packages is small.

\section{Conflict of interest: None declared.}

\section{REFERENCES}

1. Traub SJ, Hoffman RS, Nelson LS. Body packing--the internal concealment of illicit drugs. N Engl J Med 2003;349:2519-26. [CrossRef]

2. Roberts JR, Price D, Goldfrank L, Hartnett L. The bodystuf fer syndrome: a clandestine form of drug overdose. Am J Emerg Med 1986;4:24-7.

3. Kocakuşak A, Yücel AF, Arikan S, Gülen M, Koyuncu A, Asici B, et al. Clinical follow-up of patients who ingested narcotic filled bags as a rare cause of mechanical bowel obstruction: case report. Ulus Travma Acil
Cerrahi Derg 2003;9:209-11.

4. Sherman A, Zingler BM. Successful endoscopic retrieval of a cocaine packet from the stomach. Gastrointest Endosc 1990;36:152-4. [CrossRef]

5. Choudhary AM, Taubin H, Gupta T, Roberts I. Endoscopic removal of a cocaine packet from the stomach. J Clin Gastroenterol 1998;27:155-6.

6. Macedo G, Ribeiro T. Esophageal obstruction and endoscopic removal of a cocaine packet. Am J Gastroenterol 2001;96:1656-7. [CrossRef]

7. Coelho R, Orfao B, Macedo G. Successful endoscopic removal of a cocaine capsule in the stomach: should it be considered a safe therapeutic option? Endoscopy 2014;46 Suppl 1:579-80. [CrossRef]

8. Deitel M, Syed AK. Intestinal obstruction by an unusual foreign body. Can Med Assoc J 1973;109:211-2.

9. Boyer EW. Management of opioid analgesic overdose. N Engl J Med 2012;367:146-55. [CrossRef]

10. Booker RJ, Smith JE, Rodger MP. Packers, pushers and stuffers--managing patients with concealed drugs in UK emergency departments: a clinical and medicolegal review. Emerg Med J 2009;26:316-20. [CrossRef]

11. Berger FH, Nieboer KH, Goh GS, Pinto A, Scaglione M. Body packing: a review of general background, clinical and imaging aspects. Radiol Med 2015;120:118-32. [CrossRef]

12. Pinto A, Reginelli A, Pinto F, Sica G, Scaglione M, Berger FH, et al. Radiological and practical aspects of body packing. Br J Radiol 2014;87:20130500. [CrossRef]

\section{OLGU SUNUMU - ÖZET}

\section{Midede olağandışı bir yabancı cismin başarılı olarak endoskopik yöntemle tedavisi: Bir eroin paketi \\ Dr. Mehmet Asıl, Dr. Ramazan Dertli \\ Necmettin Erbakan Üniversitesi Meram Tıp Fakültesi, Gastroenteroloji Bilim Dalı, Konya}

İlaç bağımlılı̆̆ önemli bir sosyal ve tıbbi sorundur. Uyuşturucu madde kaçakçılığında "vücutta depolama” yöntemi sıklıkla kullanılmaktadır. Uyuşturucu madde küçük plastik paketler halinde hazırlandıktan sonra yutulur ya da rektum, vajina gibi doğal vücut kavitelerine yerleştirilir. Diğer benzer bir durum da uyuşturucu madde paketinin polis baskını sırasında tutuklanmamak için istemli yutulmasıdır. Biz burada eroin içeren bir paket yutan ve endoskopik olarak tedavi edilen bir olguyu sunduk. "Vücut Depolayıııları"nın yuttuğu uyuşturucu paketlerinin tedavisinde, uygun olgularda üst gastrointestinal endoskopi güvenli bir alternatif yöntemdir.

Anahtar sözcükler: Eroin; üst gastrointestinal endoskopi; vücut depolayııısı; yabancı cisim.

Ulus Travma Acil Cerrahi Derg 2017;23(4):354-356 doi: 10.5505/tjtes.2017.93462 